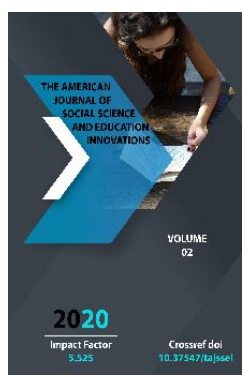

\title{
The Theory Of "Ilmi Ta'lif" (Composition) In The Work Of Kitabu-L-Musiqa Al-Kabir By Abū Nasr Al Fārābī
}

\author{
Umida Namaz qizi Sanokulova \\ Researcher, Leading Specialist, Institute Of Oriental Studies Named After Abu Rayhon Beruni \\ Of The Academy Of Sciences Of The Republic Of Uzbekistan, Tashkent, Uzbekistan
}

Journal Website:

http://usajournalshub.c

om/index,php/tajssei

Copyright: Original

content from this work

may be used under the

terms of the creative

commons attributes

4.0 licence.

\section{ABSTRACT}

This article deals with the theory of "Ilmi ta'lif" (composition), which is one of the main directions of musicology in the book "Kitabu-l-musiqa al-kabir" by Abū Nașr al Fārābī. The article provides information on the essence, components, basic concepts and elements of this theory.

\section{KEYWORDS}

“Ilmi ta'lif” (composition) theory, "Ilmi iyqo”(Rhythmic) theory, nag`ma (melody), savt, gender bu'd, intiqol.

\section{INTRODUCTION}

Abū Nașr al Fārābī was one of the great scholars of medieval Oriental music and musicology. He is best known for his work in the fields of musicology, as well as in various fields of science, such as philosophy, mathematics, geometry, astronomy, physics, medicine, and poetry.
Evaluating music as a great science, Fārābī writes that it plays an important role in mental and physical health: "This science is therefore useful because it balances the behavior of those who have lost their balance. It brings the immature to maturity, maintains the balance of those who are in balance. This science is also useful for physical health. 
Because when the body is in pain, the passion dies, and when the body is sick, the passion also feels sick. Therefore, the treatment of the body is carried out as follows: first, the passion is treated by the virtue of the voices that have such properties. Its power is reduced to the norm, adapted to the ore." [8;150]. Through these thoughts, the great scholar emphasizes the therapeutic and healing properties of the art of music, emphasizing that it is a means of curbing passion and cleansing the body.

\section{THE MAIN FINDINGS AND RESULTS}

Among the musical works of Fārābī, the book

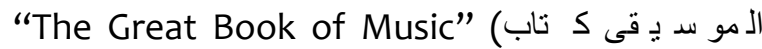
(ال ك ب ير has a special place. In this work, Fărābì divides the science of music into theoretical and practical branches, taking into account the internal structure and laws of melodies, الألث يف - ta'lif (composition) and ' الإي قاع ع لم -ilmi iyqo (rhythmics) [3; 80]. In order to facilitate the analysis of the work "Kitabu-l-musiqa al-kabir" (The Great Book of Music) in terms of thematic structure, we have divided the content into three major topics. These are:

1. "Ilmi iyqo"(Rhythmic) theory

2. "Ilmi ta'lif" (composition) theory

3. "Al-aalaat al-musiqiyya" (instruments) theory

In this article we will talk about "Ilmi ta'lif" (composition) theory. Fārābī's works on music, in particular the Great Book of Music, give a wide coverage to the theory of "Ilmi ta'lif" (composition) theory (ال تأل يف ع لم. Below we will briefly consider the extent to which this topic has been analyzed in Fārābī's work, as well as the views of post- Fārābi musicologists and his followers.
Issues related to the theory of composition in ta'lif (composition) are widely covered in the works of Abū Nașr al Fārābī and later scholars in the field of music in the Middle Ages. Fārābī's "Great Book of Music" (تاب)

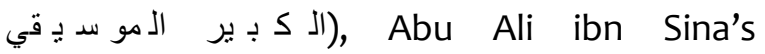

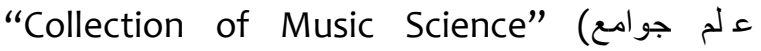
(المو سدي قي), The work of the 11th century musicologist Abu Mansur ibn Zayla, "The

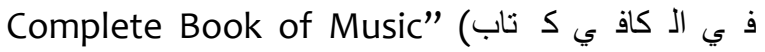
(المو سد بي قي Abdullah Khorezmi's encyclopedic work "Keys of Knowledge" (ال ع لوم مـ فات يح) dedicated to

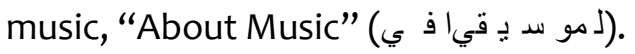

Abū Nașr al Fārābī writes in his work on the theory of music: "The scientific study of melodies and related things is called the "theoretical art of music" [9, 73]. Abu Ali ibn Sina describes the science of music as follows: "Music is a mathematical science that studies the state of melodies (nag'ma) in terms of pleasantness and unpleasantness, as well as the amount of time that passes between them melodies (nag'malar) in order to study the creation of melody. The science of music covers two issues. One of them is the discussion of the state of the tunes, which is called ta'lif (adaptation), and the other is the discussion of the amount of time that passes between the tunes. It is called the science of iyqo' (rhythm) [10;9]. One of the students of Ibn Sina, the famous 11th century musicologist Abu Mansur ibn Zayla's book “The Complete Book of Music” (المو سد قي في الـ كاف ي ك تاب ") is also one of the important sources on music theory. In it, Ibn Zayla gives a brief description of the concept of theoretical music (لناعة) (ال نظريدة المو سد بي قي :): Ash-Shaykh Abu Mansur al-Husayn ibn Muhammad ibn Umar ibn Zayla said that the science of music includes two debates. One of them is the discussion of the state of melodies (tones) in terms of their pleasantness or unpleasantness, which is 
called "Ilmi at-Ta'lif" (ال تأل يف ع لم) (The Science of Composition) - the science of adaptation (composition), the second is the debate over the amount of time that passes between the melodies, and is called "Ilmu-Iiyqo" (بـ قاعالإ عـلم) - the science of iyqo (rhythm) [5; 58]. From the above, it is clear that music theorists in their works have chosen to divide the theory of music into two main sections: the science of Ta'lif (composition) and the science of iyqo (rhythmics).

According to the definition of the term "Ilmi ta'lif" (composition) theory by the orientalist O. Matyokubov, "Ilmi ta'lif" (composition) theory (ta'lif - ar. Composed, adapted, translated as harmony or composition) gives an idea of the first particle of the melody from the sound to large musical structures. Pieces of melody: savt (sound), nag'ma (curtain, tone), bu'd (interval), jins (curtain bases of initial melody structures, four-fivestep sound lines), jam ( one-octave sound structure formed from a combination of rocks), intiqolot (displacement, modulation) categories "[4; 9]. From this definition of the scientist it is clear that "Ilmi ta"lif" (composition) theory is one of the main branches of musicology, which includes all the elements and concepts that make up the melodies and are used in their creation.

I. Rajabov also explains the concept of authorship in one of his articles. According to him, the word "ta'lif"'in Eastern music theory refers to the means of creating melodies (alhon) - musical sounds (nag'ma), their interrelationships are intervals (buds), the part that forms the lad (gender tetrachord and pentachord), one of the main areas of discussion of vowels (jams), modes and maqoms "[7; 50-51]. In medieval musicology, the theory of "Ilmi ta'lif" (composition) includes the basic concepts and principles of musicology. Sound (صوت), tone (د ندة), interval (بـ عد), volume (ثل و حدة), gender (ج نس) (i.e. tetrachord), jam' (جمع) (i.e. gamma up to two octaves) such as musicology terms such as. One of the most basic concepts in musicology, the smallest unit of elements that form the basis of musical works, is the tone, that is, the sound, which is called nag'ma in theoretical works that have survived to our time.

According to the theory of music, in "Ilmi ta'lif" (composition) theory, first of all, we are talking about the musical and physical properties of sound. We know that sound is a physical phenomenon caused by the vibration of these objects. In this theory, the relationship between the acoustics of sound, the pitch of sounds, is revealed through various musical instruments. "Songs are compared to poems and poems. In poetry, the primary element is the letters, the cause of which is vatad (weights MO), the combination of which creates lines and bytes, and in the structure of melodies there are primary and secondary elements, which are compared with the poem and the poem. the melody is derived. The only thing that plays the role of letters in poetry is melodies, " Abū Nașr al Fārābī writes. [4;12].

Ibn Zayla considers that one of the important tasks of music theory is to study the causes of sounds (nag'ma), their quality and the relationship between musical sounds. His thoughts are an example of this: "Sound is created when a percussion object touches a percussion object. The air pressure between them (percussion and percussion objects) acts as a sound wave on the sense of hearing through the ear canals. This means that the impact of an object on the body creates a melody, which is the smallest unit of music. 
Musical sounds - melodies jahāra (جهارة) resonant xafāta (خَاتَ) - without sound, hidda (جدِّ) - height and šaql (تَّل) - lowlands. Depending on the height and the low, nag'ma is judged as pleasant or unpleasant, because the two (high and low) differ and correspond to each other as quantity and number. The reason for the height depends on the hardness of the object, the degree of contact, and in other bodies on the volume, pressure, narrow or wide airway, the distance to it (from the point of delivery to the point of exit). pressure and force on the surface of the body, the disintegration of air waves, and thus reach the ear [5;59-60]. According to Ibn Zayla, each sound is determined by four

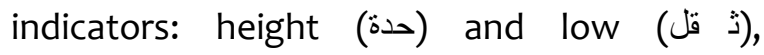
resonance (رة رةها)), silence (خَفاتة) indicators such as.

Based on this, Ibn Zayla describes the term "ta'lif" in musicology as follows: "From the point of view of the pleasantness or displeasure of melodies (tones), the discussion of their state is called Ilmu-t-ta'lif (ال تأل يف ع لم) - the science of adaptation (composition)" (British "Complete Book of Music" Manuscript kept in the museum, 220a) $[5 ; 60]$. According to this definition of the scientist, Ilmu-t-ta'lif (composition) studies the level of pleasantness and unpleasantness of musical tones, ie sounds, for hearing, as well as other related issues.

In "Ilmi ta'lif" (composition) theory, one of the main concepts after musical tones (nag'ma) and intervals (بـ (جد) with the ratio of tones is the tetrachord (جنس). Gender (جنس) The term has been variously defined by many musicologists.

Medieval music books explain that gender (ج) is the sum of at least two Buddhists. Gender is also the first syllable in the interval, and it means "tetrachord" in modern musicology[5;60]. In his book The Great Music, Abū Nașr al Fārābī defines the term "gender" as follows:

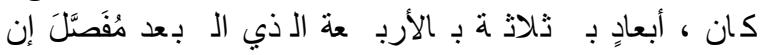

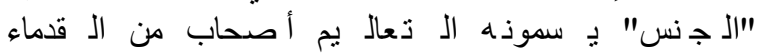
.[278;9]

The al-lazi bi al-arba'a, or quartet, which is divided into three Buddhas, was called gender by the ancient masters of this doctrine.

Ibn Sina, on the other hand, describes gender in his Collection of Music Science (لم لم جوامع)

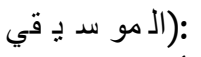

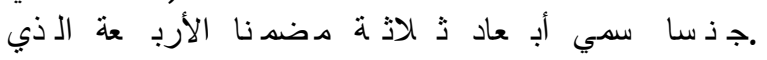
[41;10]

The al-lazi bi al-arba'a (quarta) that unites the three Buddhas was called genus.

Abu Mansur ibn Zayla, on the other hand, explains the concept of gender and gives information about its three types: "They (scholars of the past) called the al-lazi bi alarba'a (quarta), which contained three Buddhas, a genus (tetrachord), and classified the genus as follows, divided them into three classes, and named each class: 1 . The gender is strong (قوي) - strong gender (diatonic gender); 2. Gender raxv (رخو) - weak gender (chromatic gender);3. Gender is moderate (مع تدل) - moderate gender (engarmonic gender). Raxv - weak gender mulavvan (مد (د) (رد) - colorful, moderate gender rásim (را سم) - can also be called a drawing gender" ("Manuscript of the Complete Book of Music in the British Museum, 222 a) [5;61].

In The Great Book of Music, Abū Nașr al Fārābī focuses on one of the key concepts of Ilmu-tta'lif (composition) - migration, modulation (الان ت قال). In particular, Part II of the play (المو سد بـ قي صدناعة ف ي الـ ثاذ ي الا جزء) the first

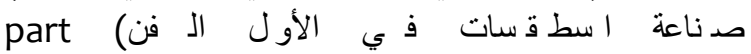




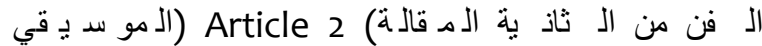

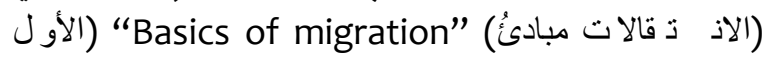
An example of this is the chapter entitled (pages 418-435). It first defines the concept of migration:

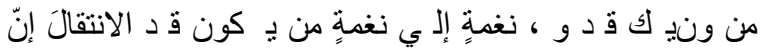

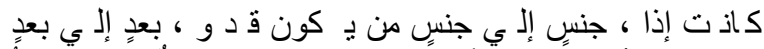

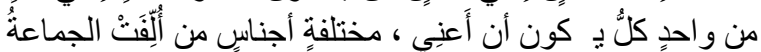

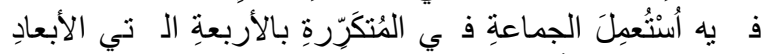

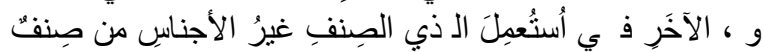

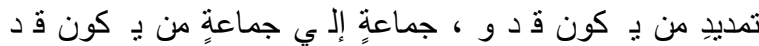
[419-418;9]

Displacement (intiqol) -- from tone (nag'ma) to tonga, interval (bud) to interval, from gender to gender (if the speaker is composed of different rocks, one type of rock in each of the repeated intervals in the speaker, another in another type can be used), from vowel to vowel, from length (length (ت مدي د) - length of tones, transposition, function) to length.

Following the definition of migration (الان تدال), Abū Nașr al Fārābī focuses on several types of migration (الان ت دال) and describes them in detail.

\section{CONCLUSION}

The theme of migration (الاذ د قال) continues in the other part of the work. The second part

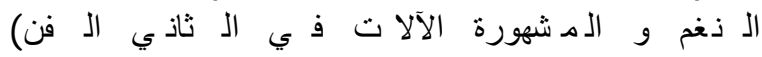

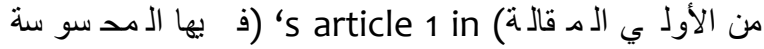
"Fundamentals of modulation and construction of melodies" (تبادئ) (الأل حان مَباني و الان د قالات The role and importance of transmissions in the structure of melodies is discussed in the chapter (959983-b). In particular, in this chapter the types of octaves, fifths and quarters (p. 965), the types of migration in octave construction: 1) shift to correctness (سد د قامة) (p. 967); 2) shift to inclination (ان عطاف) (971-b); 3) move to the circle (الس تدارة) (977-b); 4) shift to curvature (اذ عراج) (980-b) etc. are given.

The subject of migration (الان ت قال) has an important place in the theory of Ilmu-t-ta'lif (composition). The philologist, professor $\mathbf{Z}$. Aripov expresses the following opinion: “Intiqál (الان دال) - move, two parts of action music theory - Ilmu-t-ta'lif (الال تنأل يف عءل) ta'lif (composition) science and Ilmu-l-iyqá" (الإدي قاع ع لم) - is the season that connects the science of rhythm " [5;69].

In conclusion, the theory of Ilmu-t-ta'lif (composition) is considered a major issue in all works of musicology created in the Middle Ages, and all issues related to the basic concepts and principles of musicology (sound, tone, interval, gender, movement, etc.). and their species) have been analyzed and studied in the context of this topic.

\section{REFERENCES}

1. Akbarov I.A. Dictionary of music. Tashkent: Teacher, 1997.

2. An-na'im ul-kabir. Arabic-Uzbek dictionary. O. Nosirov, M. Yusupov, M. Muhiddinov and b. Namangan: Namangan, 2014.

3. Stars of spirituality (famous Central Asian figures, scholars, writers). // Abu Nasr Farobi (873-950). Edited by Khairullaev M. Tashkent: People's Heritage, 2001.

4. Matyoqubov O. Introduction to the basics of professional music in the oral tradition. Tashkent: Teacher, 1983.

5. Oripov Z.T. Terms of musicology in Ibn Zayla's Kitabu-l-kafi fi-l-musiqa. Tashkent: ToshDShl, 2008.

6. Oripov Z. Oriental musical sources (X-XI centuries). Tashkent: Science and Technology, 2008.

7. Rajabov I.R. About Fārābī's legacy in the field of music. // J. Social sciences in Uzbekistan. Tashkent: 1973. - № 6. 
8. Abū Nașr al Fārābī. About the origin of sciences. In the book: S.N. Grigoryan From the history of philosophy of Central Asia and Iran of the 7th-12th centuries. (Appendix pp. 150-151 translated from Latin by A. Rubin). Moscow: 1960.

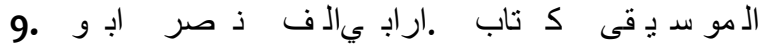

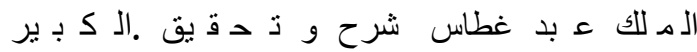

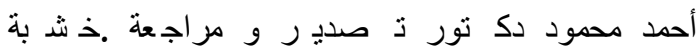

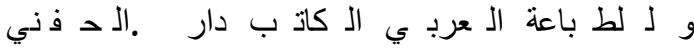

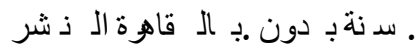

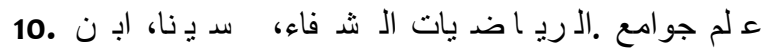

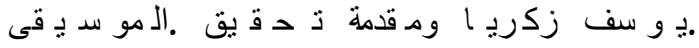

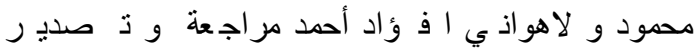

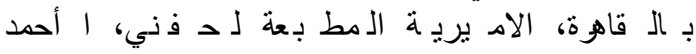
1956س. 